Article

\title{
Biochemical and Structural Analysis of a Glucose-Tolerant $\beta$-Glucosidase from the Hemicellulose-Degrading Thermoanaerobacterium saccharolyticum
}

\author{
In Jung Kim ${ }^{1}$, Uwe T. Bornscheuer ${ }^{1}$ D and Ki Hyun Nam 1,2,3,*(D)
}

Citation: Kim, I.J.; Bornscheuer, U.T.; Nam, K.H. Biochemical and Structural Analysis of a Glucose-Tolerant $\beta$-Glucosidase from the Hemicellulose-Degrading

Thermoanaerobacterium saccharolyticum. Molecules 2022, 27, 290. https:// doi.org/10.3390/molecules27010290

Academic Editor: Lothar Elling

Received: 22 September 2021

Accepted: 8 December 2021

Published: 4 January 2022

Publisher's Note: MDPI stays neutral with regard to jurisdictional claims in published maps and institutional affiliations.

Copyright: (C) 2022 by the authors. Licensee MDPI, Basel, Switzerland. This article is an open access article distributed under the terms and conditions of the Creative Commons Attribution (CC BY) license (https:// creativecommons.org/licenses/by/ $4.0 /)$.
1 Department of Biotechnology and Enzyme Catalysis, Institute of Biochemistry, University of Greifswald 17489 Greifswald, Germany; ij0308@korea.ac.kr (I.J.K.); uwe.bornscheuer@uni-greifswald.de (U.T.B.)

2 Department of Life Science, Pohang University of Science and Technology, Pohang 37673, Korea

3 POSTECH Biotech Center, Pohang University of Science and Technology, Pohang 37673, Korea

* Correspondence: structures@postech.ac.kr; Tel.: +82-10-5208-5730

\begin{abstract}
Glucosidases (Bgls) convert cellobiose and other soluble cello-oligomers into glucose and play important roles in fundamental biological processes, providing energy sources in living organisms. Bgls are essential terminal enzymes of cellulose degradation systems and attractive targets for lignocellulose-based biotechnological applications. Characterization of novel Bgls is important for broadening our knowledge of this enzyme class and can provide insights into its further applications. In this study, we report the biochemical and structural analysis of a Bgl from the hemicellulosedegrading thermophilic anaerobe Thermoanaerobacterium saccharolyticum (TsaBgl). TsaBgl exhibited its maximum hydrolase activity on $p$-nitrophenyl- $\beta$-D-glucopyranoside at $\mathrm{pH} 6.0$ and $55^{\circ} \mathrm{C}$. The crystal structure of TsaBgl showed a single $(\beta / \alpha)_{8}$ TIM-barrel fold, and a $\beta 8-\alpha 14$ loop, which is located around the substrate-binding pocket entrance, showing a unique conformation compared with other structurally known Bgls. A Tris molecule inhibited enzyme activity and was bound to the active site of TsaBgl coordinated by the catalytic residues Glu163 (proton donor) and Glu351 (nucleophile). Titration experiments showed that TsaBgl belongs to the glucose-tolerant Bgl family. The gatekeeper site of TsaBgl is similar to those of other glucose-tolerant Bgls, whereas Trp323 and Leu170, which are involved in glucose tolerance, show a unique configuration. Our results therefore improve our knowledge about the Tris-mediated inhibition and glucose tolerance of Bgl family members, which is essential for their industrial application.
\end{abstract}

Keywords: $\beta$-glucosidase; Bgl; glycoside hydrolase; cellulose degradation; glucose tolerance; Tris inhibition; Thermoanaerobacterium saccharolyticum

\section{Introduction}

Biomass-derived fuels are believed to play major roles in the global energy future, and technological development driving down costs are important for competing with petroleum and other alternative fuels [1]. Lignocellulose is a promising biomass feedstock that can be utilized for the sustainable production of biofuels and biochemicals [2]. In lignocellulosederived biorefineries, enzymatic hydrolysis is required to obtain fermentable sugars, which microorganisms can convert into fuels and value-added chemicals [3]. However, cellulose, a polymer consisting of glucose that is contained in lignocellulose, is inherently recalcitrant for enzymatic degradation and densely packed and arranged, forming a highly crystalline and insoluble structure [4]. Such a microfibril structure prevents cellulolytic enzymes from accessing the $\beta-1,4$-glycosidic bonds in cellulose [4]. Consequently, natural microbial systems require the cooperative or synergistic action of different hydrolytic cellulases, such as endoglucanase (EG), cellobiohydrolase ( $\mathrm{CBH})$, and $\beta$-glucosidase (Bgl), for the saccharification of cellulose. EGs randomly attack the internal bonds of cellulose polymer 
chains at amorphous regions, producing oligosaccharides with varying degrees of polymerization. $\mathrm{CBHs}$, also referred to as exocellulases, cleave cellulose chains either from their reducing $(\mathrm{CBH} 1)$ or nonreducing ends $(\mathrm{CBH} 2)$ in a progressive manner to yield cellobiose as the major product. This cellobiose is then converted into glucose by Bgl, making Bgl an essential enzyme in the final step of cellulose degradation [5-9].

Retaining Bgls have been found in the glycoside hydrolase (GH) families GH1, GH3, GH5, GH9, GH30, and GH116 of the CAZy database [10]. The GH1 family contains two Bgl homologs, BglA and BglB; both show hydrolase activity on cellodextrin, but differ in their quaternary structure and substrate specificity [11]. BglA is an unusual octameric cellobiase, whereas BglB is a monomeric enzyme that hydrolyzes cellobiose and cellodextrins with a high degree of polymerization [11-15]. Bgl cleaves $\beta-1,4$-glycosidic linkages in disaccharides and glucose-substituted polysaccharides and is involved in the utilization of polysaccharides as an energy source in cells $[16,17]$. Moreover, $\mathrm{Bgl}$ is widely applied in lignocellulosic biomass degradation [18]. Although various Bgls have been functionally and structurally analyzed, numerous Bgls, which are highly attractive for industrial applications, remain uncharacterized.

Thermophilic anaerobic bacteria include species with the natural ability to digest and ferment polysaccharides that constitute lignocellulosic biomass $[19,20]$. Thermoanaerobacterium saccharolyticum is a hemicellulose-degrading thermophilic anaerobe and a biological catalyst for the conversion of cellulosic biomass to ethanol [21]. This organism grows at temperatures ranging from 30 to $66^{\circ} \mathrm{C}$ and at $\mathrm{pH}$ values ranging from 3.85 to 6.35 [21]. This species ferments various carbohydrates, such as glucose, cellobiose, xylan, xylose, starch, arabinose, mannose, and galactose, but cannot degrade crystalline cellulose [22] Various thermophilic enzymes, which can be applied in industry, have been isolated and characterized from T. saccharolyticum, including endoxylanase [23], $\beta$-xylosidase [24], glucuronidase [25], and amylopullanase [26]; however, Bgl, the terminal enzyme of the cellulose degradation process, is still unknown.

In this study, we report the biochemical and structural analysis of $\mathrm{Bgl}$ from T. saccharolyticum (TsaBgl). We investigated the substrate specificity, optimum temperature and $\mathrm{pH}$, and thermal stability of TsaBGl and the effects of metals on this enzyme. A high-resolution crystal structure of TsaBGl was determined at $1.7 \AA$, showing the binding of the inhibitor Tris to the active site. Moreover, a titration experiment of TsaBgl using Tris and glucose molecules was performed. Our results showed that the favorable properties of TsaBgl could be used in the field of biotechnology and provide useful information to broaden our structural knowledge of the Bgl family.

\section{Results}

\section{1. $\beta$-Glucosidase Activity of TsaBgl}

TsaBgl, codon-optimized for E. coli host expression, was overexpressed in E. coli BL21 (DE3). The protein was eluted at a molecular mass position of approximately $50 \mathrm{kDa}$ during size exclusion chromatography, which was almost identical to the theoretical molecular weight of TsaBgl (51.728 kDa), indicating that TsaBgl was a monomer in solution (Figure 1a). The enzyme activity and substrate specificity of purified TsaBgl were determined using various $p$-nitrophenyl glycosides ( $p$ NPG, $p$ NPC, and $p \mathrm{NP} \alpha \mathrm{G}$ ) as substrates. $p \mathrm{NPG}$ and $p$ NPC were selected based on the fact that Bgls often possess hydrolyzing activity towards soluble cellodextrins, including cellobiose and cellotriose. In addition, $\alpha$-bonded- $p \mathrm{NP} \alpha \mathrm{G}$ was chosen to examine the preferred linkage type in TsaBgl. Our results show that TsaBgl exhibited the highest hydrolase activity on the artificial substrate $p$ NPG with a specific activity of $23.6 \mathrm{U} / \mathrm{mg}$. Moreover, the relative hydrolase activity of TsaBgl toward $p$ NPC was $19.71 \%$ of that toward $p$ NPG; however, no enzyme activity was observed on $p \mathrm{NP} \alpha \mathrm{G}$ (Figure 1b). 
a

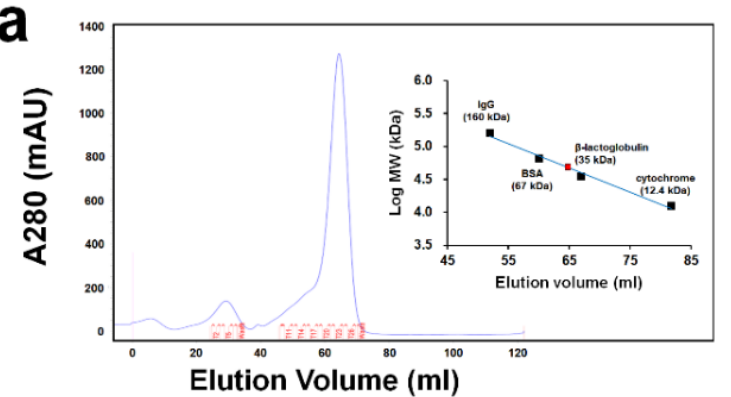

b

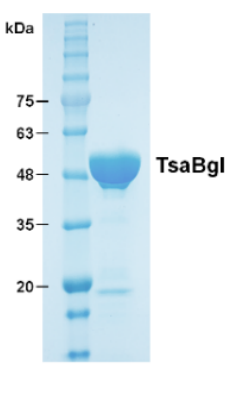

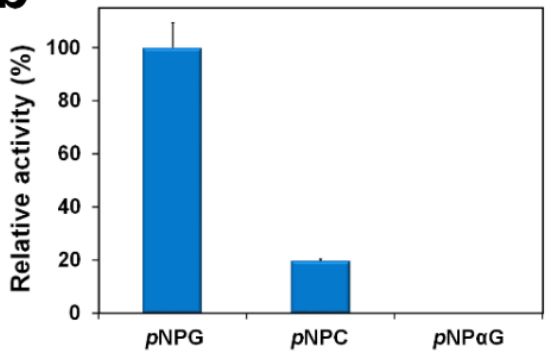

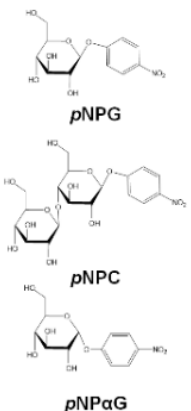

pNPaG
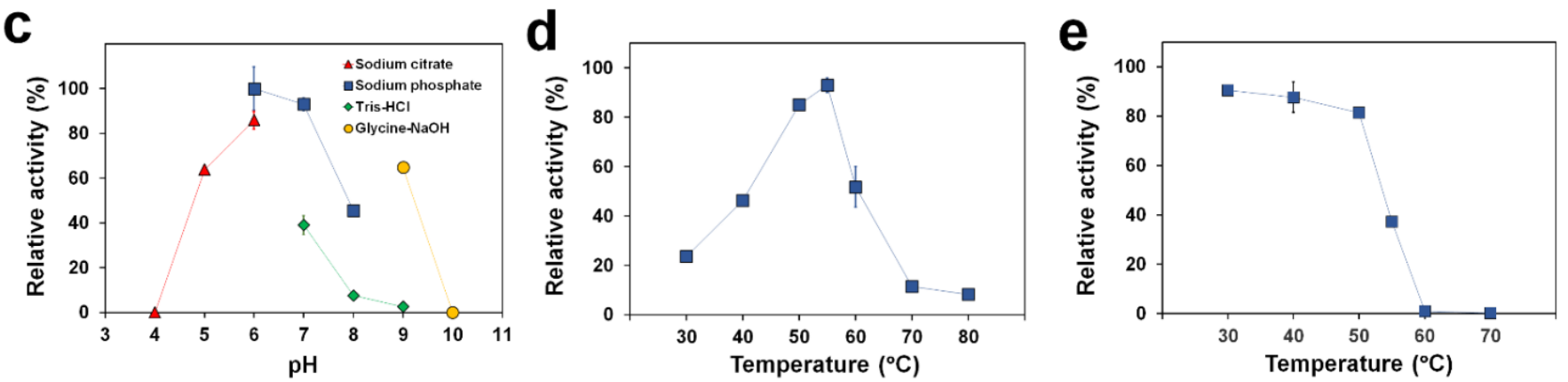

Figure 1. Characterization of the $\beta$-glucosidase activity of TsaBgl. (a) Elution profile of TsaBgl on gel filtration chromato-graphy and purified protein. (b) Enzyme activity of TsaBgl towards various p-nitrophenyl substrates at $55{ }^{\circ} \mathrm{C}$ in $100 \mathrm{mM}$ sodium phosphate (pH 6.0). (c) Enzyme activity of TsaBgl at various $\mathrm{pH}$, ranging from $\mathrm{pH} 4$ to 10 , at $55^{\circ} \mathrm{C}$. (d) Enzyme activity of TsaBgl at various temperatures ranging from 30 to $80^{\circ} \mathrm{C}$ in $100 \mathrm{mM}$ sodium phosphate buffer ( $\mathrm{pH} 7.0$ ). Relative activity in panels $(\mathbf{b}-\mathbf{d})$ is defined as the enzyme activity relative to that obtained at $\mathrm{pH} 6.0(100 \mathrm{mM}$ sodium phosphate) and $55{ }^{\circ} \mathrm{C}$ with $p$ NPG, set as $100 \%$, with a specific activity of $23.6 \mathrm{U} / \mathrm{mg}$. (e) Thermal stability of TsaBgl. The enzyme was pre-incubated at $30,40,50,60$, and $70{ }^{\circ} \mathrm{C}$ for 10 min without substrate, after which residual activities were measured under the standard conditions as detailed in the Materials and Methods section. The activity without pre-incubation was set as $100 \%$, where the specific activity was $23.6 \mathrm{U} / \mathrm{mg}$, and residual activities were calculated as its percentage. Error bars represent the standard deviations of three independent experiments.

Next, the optimal temperature and $\mathrm{pH}$ for TsaBgl enzyme activity were investigated using $p$ NPG as a substrate. For both profiles, the activity at pH $6.0(100 \mathrm{mM}$ sodium phosphate) and $55{ }^{\circ} \mathrm{C}$ was defined as $100 \%$, where the specific activity was $23.6 \mathrm{U} / \mathrm{mg}$. The hydrolase activity of TsaBgl was investigated in the $\mathrm{pH}$ range of 4.0-10.0 using a four buffer system (Figure 1c). The maximum enzyme activity of TsaBgl was obtained at $\mathrm{pH}$ 6.0, and at $\mathrm{pH} 5.0,7.0$, and 9.0, the relative activity was still higher than $60 \%$. Additionally, the relative activity was nearly zero at $\mathrm{pH} 4.0$ and 10.0. Although generally approved, such a system using different buffers can sometimes cause a significant deviation in activity values at the same $\mathrm{pH}$ (but in different buffers), especially when the target enzyme is sensitive to a certain buffer component. Notably, the enzyme activities determined from $\mathrm{pH} 7.0$ to 9.0 using Tris- $\mathrm{HCl}$ buffer were much lower than those obtained in sodium phosphate and glycine-NaOH buffers (Figure 1c). This implied that the Tris molecule could act as a competitive inhibitor of TsaBgl (see below). Therefore, Tris would not be a good buffer for application of TsaBgl; other buffers, such as phosphate-based buffers, should be used instead, in the same $\mathrm{pH}$ range. However, the final concentration of Tris at $1 \mathrm{mM}$, derived from the storage buffer ( $10 \mathrm{mM}$ Tris- $\mathrm{HCl}$ with $200 \mathrm{mM} \mathrm{NaCl}$; $\mathrm{pH}$ 8.0), in our enzyme assays did not significantly affected the activity of TsaBgl compared to that in a reaction without $1 \mathrm{mM}$ Tris $(p<0.05)$ (Figure S1).

The enzyme activity of TsaBgl was then determined over a temperature range of $30-70{ }^{\circ} \mathrm{C}$ (Figure 1d). Maximum enzyme activity was obtained at $55^{\circ} \mathrm{C}$, and the relative activity was still $91 \%$ at $50{ }^{\circ} \mathrm{C}$. However, the activity dropped sharply at $60{ }^{\circ} \mathrm{C}$ (relative 
activity: $\sim 55 \%$ ), and at $70{ }^{\circ} \mathrm{C}$, only $12 \%$ of the relative activity was left. In addition to the reaction rate, it is important to examine the enzyme stability in response to heat when considering its industrial applications. We found that after $10 \mathrm{~min}$ of incubation at 30, 40, and $50{ }^{\circ} \mathrm{C}$, more than $80 \%$ of the activity of TsaBgl was retained (Figure 1e). However, the residual activity dramatically decreased to $37 \%$ at $55{ }^{\circ} \mathrm{C}$, and only a little activity remained at $60{ }^{\circ} \mathrm{C}$. These results indicated that, although the activity of TsaBgl was highest at $55{ }^{\circ} \mathrm{C}$, the structure was not sufficiently stable to maintain its conformation and activity at this temperature.

The effects of metal ions on TsaBgl activity were also assessed (Table 1). The specific activity without any metal ion was $25.9 \mathrm{U} / \mathrm{mg}$. As a result, no metal ion distinctively stimulated enzyme activity. In contrast, activity was markedly reduced in the presence of $1 \mathrm{mM} \mathrm{Cd}^{2+}, \mathrm{Zn}^{2+}, \mathrm{Cu}^{2+}$, and $\mathrm{Fe}^{2+}$ compared with that in the absence of any metal. The inhibition trend was as follows: $\mathrm{Cu}^{2+}>\mathrm{Zn}^{2+}>\mathrm{Cd}^{2+}$ and $\mathrm{Fe}^{2+}$, with relative activities of $8.7 \%, 25.2 \%, 68.2 \%$, and $71.2 \%$, respectively (Table 1 ).

Table 1. Effect of metal ions on activity of TsaBgl.

\begin{tabular}{cc}
\hline Metal & Relative Activity (\%) \\
\hline $\mathrm{None}^{\mathrm{a}}$ & $100.00 \pm 3.05$ \\
$\mathrm{Li}^{+}$ & $98.66 \pm 2.93$ \\
$\mathrm{Mg}^{2+}$ & $97.26 \pm 4.83$ \\
$\mathrm{Ca}^{2+}$ & $90.80 \pm 2.37$ \\
$\mathrm{Mn}^{2+}$ & $97.64 \pm 5.38$ \\
$\mathrm{Fe}^{2+}$ & $69.46 \pm 2.43$ \\
$\mathrm{Fe}^{3+}$ & $91.02 \pm 0.57$ \\
$\mathrm{Co}^{2+}$ & $92.23 \pm 5.69$ \\
$\mathrm{Ni}^{2+}$ & $85.07 \pm 3.23$ \\
$\mathrm{Cu}^{2+}$ & $8.47 \pm 0.50$ \\
$\mathrm{Zn}^{2+}$ & $24.63 \pm 0.98$ \\
$\mathrm{Cd}^{2+}$ & $66.53 \pm 4.07$ \\
$\mathrm{Ce}^{2+}$ & $96.03 \pm 3.89$
\end{tabular}

a None represents the enzymatic reaction in the absence of any metal ion, where the specific activity was $25.9 \mathrm{U} / \mathrm{mg}$.

Kinetic parameters for TsaBgl were obtained with respect to 0 to $10 \mathrm{mM} p \mathrm{NPG}$ under the standard conditions, wherein $K_{m}, k_{\text {cat }}$, and $k_{\text {cat }} / K_{m}$ were $0.36 \mathrm{mM}, 18.62 \mathrm{~s}^{-1}$, and $50.99 \mathrm{mM}^{-1} \mathrm{~s}^{-1}$, respectively.

\subsection{Overall Structure of TsaBgl}

To better elucidate the molecular function of TsaBgl, we determined the crystal structure of TsaBgl at $1.70 \AA$ resolution (Table 2). Crystals of TsaBgl belonged to the orthorhombic space group $\mathrm{P} 2{ }_{1}{ }_{1} 2_{1}$ with one molecule per asymmetric unit. The final $\mathrm{R}_{\text {work }}$ and $\mathrm{R}_{\text {free }}$ of the TsaBgl model were $14.10 \%$ and $18.23 \%$, respectively.

TsaBgl contained $16 \alpha$-helices and $13 \beta$-strands, forming a single $(\beta / \alpha)_{8}$ TIM-barrel fold with dimensions of $55 \times 55 \times 50 \AA$ (Figure $2 \mathrm{a}$ ). During the structure refinement, strong Fo-Fc electron density was observed in the active site pocket corresponding to the Tris molecule of the buffer solution (Figure S2), which was characterized as an inhibitor in our biochemical study (Figure 1c). Interactions between the N-terminus of TsaBgl (Asp3, Phe4, Ser5, Lys6, and Phe8) and its C-terminus (Arg442, Thr443, and Ieu444) were observed (Figure S3), and these interactions were involved in protein stability [27]. The conserved active site containing the crucial residues Glu163 (proton donor) and Glu351 (nucleophile), which are involved in the acid-base mechanism, is located in the center of the TIM-barrel (Figure 2a). Temperature factor analysis showed that the core of the TIM-barrel of TsaBgl was highly rigid, whereas the loop between the $\beta 8$-strand and $\alpha 14$-helix (named the $\beta 8$ - $\alpha 14$ loop) showed structural flexibility and was $\sim 20 \AA$ away from the substrate-binding entrance 
(Figure 2b). In particular, residues between Gln300 and Arg318 in the $\beta 8$ - $\alpha 14$ loop (B-factor value: $33.92 \AA^{2}$ ) exhibited a considerably higher B-factor than the whole protein $\left(17.37 \AA^{2}\right)$.

Table 2. Data collection and refinement statistics for TsaBgl.

\begin{tabular}{|c|c|}
\hline Data Collection & TsaBgl \\
\hline Space group & $\mathrm{P} 2{ }_{1} 2_{1} 2_{1}$ \\
\hline $\begin{array}{l}\text { Cell dimensions } \\
\text { a, b, c }(\AA)\end{array}$ & $65.139,71.293,99.240$ \\
\hline Resolution $(\AA)$ & $50.0-1.70(1.73-1.70)$ \\
\hline Completeness & $98.4(97.1)$ \\
\hline Redundancy & $5.7(4.1)$ \\
\hline $\mathrm{I} / \sigma(\mathrm{I})$ & $16.50(2.38)$ \\
\hline $\mathrm{R}_{\text {merge }}{ }^{a}$ & $0.135(0.423)$ \\
\hline $\mathrm{CC} 1 / 2$ & $0.979(0.663)$ \\
\hline$C C^{*}$ & $0.995(0.893)$ \\
\hline \multicolumn{2}{|l|}{ Refinement statistics } \\
\hline Resolution $(\AA)$ & $49.67-1.70$ \\
\hline$R_{\text {work }}(\%) b$ & 14.10 \\
\hline $\mathrm{R}_{\text {free }}(\%)^{\mathrm{c}}$ & 18.23 \\
\hline \multicolumn{2}{|l|}{ B-factor (Averaged) } \\
\hline Protein & 17.37 \\
\hline Tris & 29.07 \\
\hline Solvent & 33.10 \\
\hline \multicolumn{2}{|l|}{ R.m.s deviations } \\
\hline Bond lengths ( & 0.013 \\
\hline Bond angles $\left({ }^{\circ}\right)$ & 1.635 \\
\hline \multicolumn{2}{|l|}{ Ramachandran plot (\%) } \\
\hline favored & 97.06 \\
\hline allowed & 2.94 \\
\hline
\end{tabular}

Highest resolution shell is shown in parentheses. ${ }^{a} \mathrm{R}_{\text {merge }}=\Sigma_{h} \Sigma_{i}\left|\mathrm{I} i(\mathrm{hkl}) \_<\mathrm{l}(\mathrm{hkl})>\right| / \Sigma_{h} \Sigma_{i} \mathrm{I}_{i}(\mathrm{hkl})$, where $I_{i}(\mathrm{hkl})$ is the intensity of the 'ith' measurement of reflection $h \mathrm{kl}$ and $\langle I(\mathrm{hkl})\rangle$ is the weighted mean of all measurements of hkl. ${ }^{\mathrm{b}} \mathrm{R}_{\text {work }}=\Sigma|| F_{\text {obs }}|-| F_{\text {calc }}|| / \Sigma\left|F_{\text {obs }}\right|$, where $F_{\text {obs }}$ and $F_{\text {calc }}$ are the observed and calculated structurefactor amplitudes, respectively. ${ }^{c} R_{\text {free }}$ was calculated as $R_{\text {work }}$ using a randomly selected subset (5\%) of unique reflections not used for structure refinement.

The results of the structural homology search showed that TsaBgl shared high structural similarities with Bgls from Halothermothrix orenii (HorBglB, PDB code: 4PTX, Z-score: 63.3, sequence identity: 52.32\%), Exiguobacterium antarcticum (EanBglB, 5DT7, 63.1, 50.78\%), Clostridium cellulovorans (CceBglB, 3AHX, 61.9, 53.23\%), and Thermotoga maritima (TmaBglB, $2 J 79,61.7,47.78 \%$ ). Superimposition of the TsaBgl structure with those of the homologous Bgls showed high similarity, with r.m.s. deviations of 0.49-0.61 A (Figure S4). Additionally, pronounced differences in the conformations of their $\beta 8-\alpha 14$ loops were also observed (Figure $2 \mathrm{c}$ ). These loop regions did not have sequence similarity with each other (Figure $2 \mathrm{~d}$ ).

\subsection{Tris-Binding at the Active Site of TsBgl}

The substrate-binding pocket of TsaBgl, including the active site, is located in the center of the TIM-barrel fold (Figure 3a). The part of the $\beta 8-\alpha 14$ loop pointing toward the substrate-binding pocket and the part of the entrance of the substrate-biding pocket in the vicinity of the $\beta 8-\alpha 14$ loop forms a hydrophobic surface with an area of approximately $5 \times 16 \AA$ (Figure 3b). In particular, the area and shape of this hydrophobic surface depended on the conformation of the $\beta 8-\alpha 14$ loop. The size of the entrance of the substrate-binding pocket was approximately $5 \times 8 \AA$ (Figure $3 a$ ), and the distance from the entrance surface to the active site was approximately $15 \AA$ (Figure 3b). Thus, linear sugar substrates, such as cellobiose and $p N P G$, could access and intrude into the substrate-binding site, whereas bulky sugar substrates, such as branched sugars, could not pass through the gatekeeper region in the substrate binding site. 
a
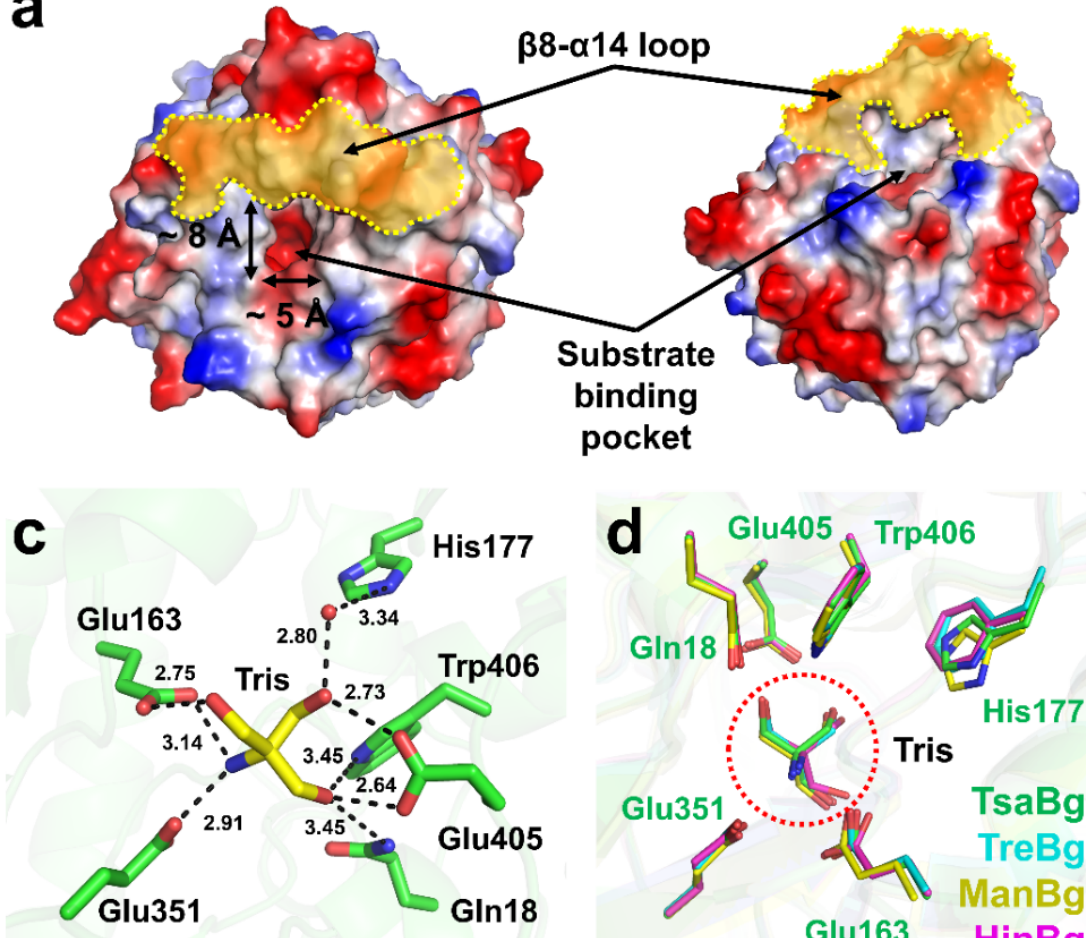

b

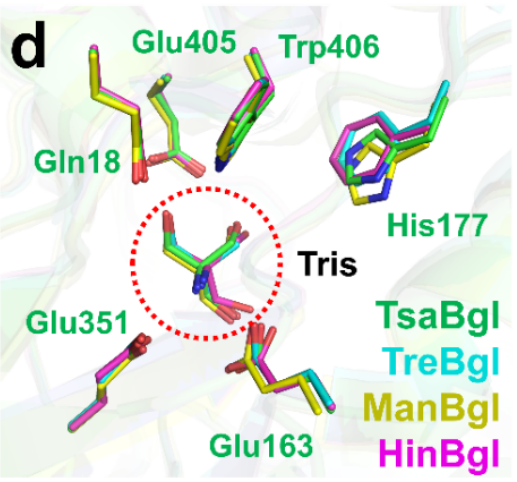

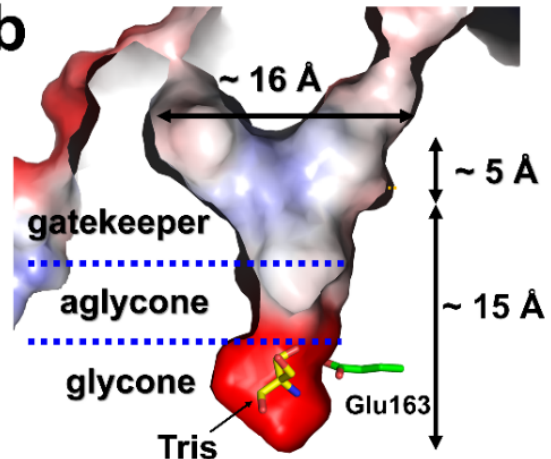

Tris

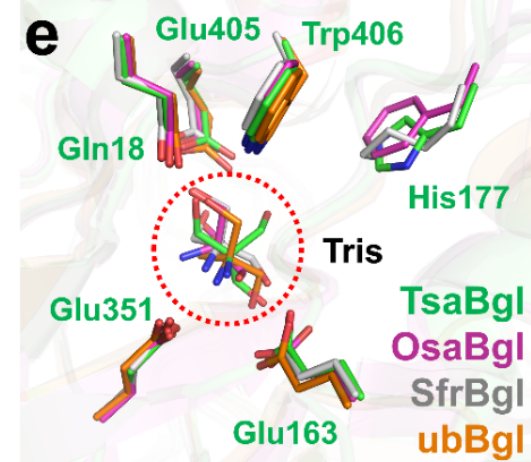

Figure 3. Substrate-binding pocket and active site of TsaBgl. (a) Electrostatic potential surface of the substrate-binding site of TsaBgl. The $\beta 8-\alpha 14$ loop is indicated by a yellow dotted line. (b) Substrate binding channel of TsaBgl. Tris is bound to the glycone region of TsaBgl. (c) Interactions between the Tris molecule and the residues of the substrate-binding site in TsaBgl. The interacting residues Glu163 and Glu351 are catalytic residues for Bgl activity. (d) Similar Tris-binding configurations of TsaBgl with TreBgl (PDB code: 3AHY), ManBgl (3W53), and HinBgl (4MDO). (e) Different Tris-binding configuration of TsaBgl and OsaBgl (4RE2), SfrBgl (5CG0) and ubBgl (6IER).

On the other hand, in the structures OsaBgl2, the Tris molecule was located in the binding channel or at the surface of the TIM-barrel.

\subsection{Titration of Tris and Glucose on TsaBgl}

Glucose produced by the Bgl-catalyzed decomposition of cellobiose is known to act as a product inhibitor [35]. This is a potential problem preventing the production efficiency in industrial applications. To investigate the binding mode of glucose, we soaked TsaBgl crystals with various concentrations of glucose for more than $1 \mathrm{~h}$ before collection of diffraction data. The results show that no electron density corresponding to glucose was observed in the active site of TsaBgl, but a Tris molecule bound to the active site in the same way as in the native crystal structure of TsaBgl. Therefore, we assumed that glucose might have a lower binding affinity for the active site of TsaBgl than Tris. To provide experimental evidence for this, we performed an analysis of hydrolysis inhibition of TsaBgl through titration experiments on Tris and glucose molecules. Relative activity (\%) in each panel represented the enzyme activity relative to that obtained under the condition lacking any inhibitory molecule (i.e., Tris or glucose), the latter being defined as 100\%. Specific activity in the absence of Tris or glucose was 19.1 or $22.7 \mathrm{U} / \mathrm{mg}$, respectively. The enzyme activity of TsaBgl was significantly inhibited by the Tris molecule (Figure 4a). A Tris concentration of $10 \mathrm{mM}$ reduced the enzyme activity by half. In the presence of $80 \mathrm{mM}$ Tris, only $15 \%$ of the activity remained. In contrast, TsaBgl maintained its full activity, even at glucose concentrations of up to $100 \mathrm{mM}$, and in the presence of $200 \mathrm{mM}$ glucose, $80 \%$ of the maximum activity (without glucose) still remained (Figure $4 \mathrm{~b}$ ). The inhibition concentration of glucose that reduced the activity of TsaBgl by half was approximately 
$650 \mathrm{mM}$; however, even at higher glucose concentrations of up to $830 \mathrm{mM}$, the enzyme still showed a relative activity of $34 \%$. Therefore, the enzyme was more sensitive to Tris than to glucose, and its activity sharply declined, even at low concentrations of Tris. The observation that TsaBgl maintained its activity, even in the presence of such high glucose concentrations, indicates that TsaBgl is a glucose-tolerant Bgl. Taken together, these findings demonstrate that the Tris molecule acts as inhibitor of TsaBgl and that TsaBgl belongs to the glucose-tolerant Bgl family.

a

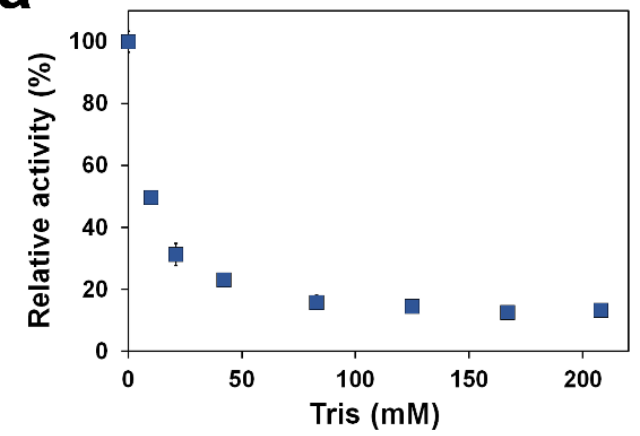

b

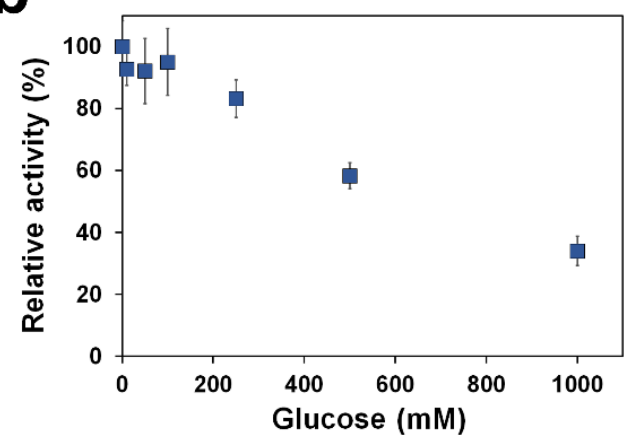

Figure 4. Enzyme activity of TsaBgl under various concentrations of (a) Tris (pH 7.0 with $100 \mathrm{mM}$ sodium phosphate) and (b) glucose (pH 6.0 in $100 \mathrm{mM}$ sodium phosphate) was performed at $55^{\circ} \mathrm{C}$ using $p$ NPG as substrate. Relative activity (\%) in each panel represents the enzyme activity relative to that obtained under conditions lacking any inhibiting molecule (i.e., Tris or glucose), defined as $100 \%$, where the specific activities were 22.7 and $19.1 \mathrm{U} / \mathrm{mg}$, respectively. Error bars represent the standard deviations of three independent experiments.

\section{Discussion}

Bgls are essential terminal enzymes of the cellulase system and attractive targets for lignocellulose-based biotechnological applications. To discover a novel $\mathrm{Bgl}$ and broaden the knowledge of this enzyme class at the molecular level, we performed biochemical and structural analyses of $\mathrm{Bgl}$ from the hemicellulose-degrading thermophilic anaerobe T. saccharolyticum. The growth $\mathrm{pH}$ and temperature of the T. saccharolyticum strain were 3.85-6.35 and $30-66^{\circ} \mathrm{C}$, respectively. Purified recombinant TsaBgl showed high activity at $\mathrm{pH} 6.0$ and $50-55{ }^{\circ} \mathrm{C}$, but the activity decreased to less than $60 \%$ at other $\mathrm{pH}$ and temperature values. In addition, TsaBgl showed the highest enzyme activity at $55{ }^{\circ} \mathrm{C}$, although thermostability experiments revealed that the residual activity was reduced by $37 \%$ after $10 \mathrm{~min}$. As a result, the in vitro enzymatic activity of purified TsaBgl was not as consistent over a broad $\mathrm{pH}$ and temperature range as the growth of the strain.

A previous study had classified the Bgl family into five clades: Clade I (mainly mesophilic bacteria), Clade II (GH1 Bgl from fungi), Clade III (GH3 Bgl from bacteria), Clade IV (GH3 Bgl from fungi), and Clade V (thermophile or Bacillus GH1 Bgl) [36]. Taxonomic analysis showed that TsaBgl belongs to Clade $\mathrm{V}$ and has close evolutionary relationships with Thermoanaerobacterium thermosaccharolyticum (Figure S6). In addition, TsaBgl exhibits high amino acid sequence identity of $87.2 \%$ (similarity of $94 \%$ ) to Bgl from Thermoanaerobacterium thermosaccharolyticum (named TthBgl). Despite the close relationship between TsaBgl and TthBgl, there are several notables differences in their enzymatic activity. Specifically, the optimum temperature of TsaBgl and TthBgl for enzyme activity are 55 and $70{ }^{\circ} \mathrm{C}$, respectively. Moreover, the activity of TsaBgl was not affected by $\mathrm{Mn}^{2+}$ and inhibited by $\mathrm{Fe}^{2+}$ while the activity of TthBgl was activated by both $\mathrm{Mn}^{2+}$ and $\mathrm{Fe}^{2+}$. Such a discrepancy may arise from a difference in the reaction buffer between the two studies (sodium phosphate vs. imidole-potassium). Since phosphate often forms an insoluble complex with metal ions, in our study, effects of $\mathrm{Fe}^{2+}$ and $\mathrm{Mn}^{2+}$ might have been either insignificant or inhibitory in phosphate buffer. Furthermore, in the current study, TsaBgl was incubated with metal ions in the presence of the substrate while TthBgl was pre- 
incubated with metal ions prior to substrate addition. Since the latter had a longer time for direct interaction with metal ions that might explain the discrepancy between the two enzymes regarding activities in the presence of $\mathrm{Mn}^{2+}$.

Kinetic parameters of TsaBgl were compared to those of other Bgls belonging to $\mathrm{GH}$ family 1 . The parameters of different Bgls showed distinct values (Table 2). The $K_{m}$ value of TsaBgl, which represents binding affinity, was slightly lower or comparable to that of other Bgls, indicating for TsaBgl, in general, to have a higher or similar binding affinity relative to GH1 Bgls. While the $k_{\text {cat }}$ values, the turnover number of substrate, were similar across TsaBgl, EanBgl, and CceBgl, TsaBgl showed higher values than TrBgl2 and NkoBgl by approximately 3 and 13 fold, respectively, whereas this value was 24 -fold lower than that of TmaBglA. The overall catalytic efficiency of TsaBgl for $p$ NPG $\left(k_{c a t} / K_{m}\right)$ compared to that of EanBglA was higher than those reported for TreBgl2 and NkoBgl, but 7- and 24-fold lower than those reported for CceBglA and TmaBglA, respectively.

The catalytic efficiency $\left(k_{c a t} / K_{m}\right)$ of TsaBgl was similar to that of EanBglA, another glucose-tolerant GH1, but much higher than those of TrsBgl2 and NkoBgl (Table 3), whose active sites are known to be occupied and actions are inhibited by Tris, like in TsaBgl reported in our study. Conversely, the catalytic efficiency of CceBgl and TmaBglA were much higher than those of TsaBgl. In particular, TmaBglA was exceptionally superior in terms of catalytic efficiency, which might be owing to its hyperthermostability. However, to the best of our knowledge, none of the two enzymes had been reported to be glucose-tolerant and thus, TsaBgl with glucose-tolerance could be a good candidate for industrial application.

Table 3. Comparison of kinetic parameters across the GH family $1 \mathrm{Bgls}^{\mathrm{a}}$.

\begin{tabular}{|c|c|c|c|c|c|}
\hline Enzyme & $K_{m}(\mathrm{mM})$ & $k_{\text {cat }}\left(\mathrm{s}^{-1}\right)$ & $k_{c a t} / K_{m}\left(\mathrm{mM}^{-1} \mathrm{~s}^{-1}\right)$ & Optimal Conditions & Reference \\
\hline TsaBgl & $0.36 \pm 0.02$ & $18.62 \pm 0.32$ & $50.99 \pm 2.28$ & $\mathrm{pH} 6,55^{\circ} \mathrm{C}$ & This study \\
\hline TthBgl & 0.63 & $\mathrm{ND}^{\mathrm{b}}$ & $\mathrm{ND}^{\mathrm{b}}$ & $\mathrm{pH} 6.4,70^{\circ} \mathrm{C}$ & [36] \\
\hline EanBglA & 1.07 & 32.98 & 30.8 & $\mathrm{pH} 7,30^{\circ} \mathrm{C}$ & [37] \\
\hline CceBglA & $0.15 \pm 0.01$ & $50.67 \pm 1.00$ & $340 \pm 27$ & $\mathrm{pH} 6,45^{\circ} \mathrm{C}$ & [29] \\
\hline TreBgl2 & $0.86 \pm 0.07$ & $6.91 \pm 0.16$ & $8.1 \pm 0.8$ & $\mathrm{pH} 6,40{ }^{\circ} \mathrm{C}$ & [29] \\
\hline NkoBgl & $0.29 \pm 0.02$ & $1.39 \pm 0.03$ & $4.8 \pm 0.4$ & $\mathrm{pH} 5.5,45^{\circ} \mathrm{C}$ & [29] \\
\hline TmaBglA & $0.38 \pm 0.02$ & $452.27 \pm 8.25$ & $1210 \pm 140$ & $\mathrm{pH} 6.2,90^{\circ} \mathrm{C}$ & [38] \\
\hline
\end{tabular}

a Parameters compared here were obtained using $p$ NPG as the substrate. ${ }^{b}$ ND represents "not determined" in the reference.

The sequence similarity between TsaBgl and other structurally known Bgls was less than $53 \%$. Although the overall TIM-barrel fold was similar among all Bgls, the $\beta 8$ - $\alpha 14$ loop of TsaBgl showed a unique conformation. As loops near the substrate-binding site of Bgl can be flexible during substrate binding [39], we assumed that the $\beta 8-\alpha 14$ loop of TsaBgl may adopt another conformation during substrate recognition. Moreover, the unique conformation of the $\beta 8-\alpha 14$ loop of TsaBgl structurally supported the suggestion that variations in the substrate recognition loop of the Bgl family could be varied.

Tris molecules often act as inhibitors to reduce the hydrolytic enzyme activity of Bgl [40-42], and this molecule is presumed to mimic the substrate because it is rich in hydroxyl groups $[11,30]$. Our biochemical results showed that the enzyme activity of TsaBgl was also reduced by Tris. In the current study, TsaBgl was purified and stored in Tris buffer. When the TsaBgl solution stored in $10 \mathrm{mM}$ Tris buffer was diluted with other buffers, such as phosphate and glycine, the enzyme activity was increased, indicating that Tris could be released from TsaBgl in the presence of low concentrations of Tris. Analysis of the crystal structure of TsaBgl showed that one Tris molecule is bound to the glycone site and interacted with Glu163 and Glu351, which are involved in the hydrolytic activity of TsaBgl. The binding configuration of Tris bound to TsaBgl was almost identical to those of TreBgl, ManBgl, and HthBgl (Figure 3d), but different from those of OsaBgl, SfrBgl, and ubBgl (Figure 3e). Additionally, among the Bgl structures deposited in the PDB, some structures showed that Tris did not bind to the active site despite the use of Tris buffer 
during purification or crystallization; these Bgls are expected to have no high binding affinity with Tris. Collectively, our findings suggest that the inhibitory effects of Tris on enzyme activity varied for each Bgl. These results are meaningful because Tris may limit the potential industrial applications of some Bgls. On the other hand, if the active site is occupied by Tris, the actual substrate cannot directly access the substrate-binding site, thereby reducing enzyme activity because additional steps are required to remove Tris from the substrate-binding site. Therefore, when measuring the enzyme activities of Bgls, buffers other than Tris (e.g., phosphate-based buffers) should be tested in the same $\mathrm{pH}$ range; this could be important for optimizing enzyme activity for industrial applications.

During the production of biofuels or biochemicals derived from lignocellulosic biomass, a high titer of glucose is generated. In addition, glucose, the end-product of the catalytic reaction of $\mathrm{Bgl}$, can inhibit enzyme activity and often poses a limitation on the use of Bgls in industrial applications [35]. To better understand glucose recognition of TsaBgl, we performed a soaking experiment to bind glucose to TsaBgl; however, in all crystal structures, Tris, not glucose, was bound to the active site, indicating that glucose had lower binding affinity than Tris. This result is consistent with a titration experiment for TsaBgl using Tris and glucose, which showed that TsaBgl belonged to the glucose-tolerant Bgl family.

Depending on the effects of glucose on enzyme activity, Bgls can be divided into three groups [43]: (1) those that are strongly inhibited by low concentrations of glucose (including most Bgls); (2) those that are resistant to low levels of glucose, but inhibited by high glucose; and (3) those that are stimulated by low glucose levels and inhibited by high glucose levels. TsaBgl belongs to the second group and showed activity that was resistant to glucose at concentrations of up to $0.3 \mathrm{M}$, but inhibited (50\% of original activity) by $0.65 \mathrm{M}$ glucose.

Previous studies have identified several key amino acids that influence glucose tolerance, most of them at the substrate entrance site [44-46]. In particular, hydrophobic interactions of tryptophan and leucine resides contribute to relieving enzyme inhibition by imposing constraints at the gatekeeper region that limit the access of glucose to the glycone site [31,44]. These two residues are conserved in TsaBgl (Figure S5).

To understand the structural basis of glucose tolerance better, we compared the TsaBgl structure with those of the previously reported glucose-tolerant engineered Trichoderma harzianum Bgl (ThaBgl) and the high glucose-tolerant Humicola insolens Bgl (HinBgl). TsaBgl showed amino acid sequence identities of 38.0 and $36.0 \%$ with ThaBgl-Mut and $\mathrm{HinBgl}$, respectively. Structural superposition of ThaBgl-Mut and HinBgl to TsaBgl showed r.m.s. deviation of 0.723 and $0.678 \AA$, respectively. In a previous study of ThaBgl, double amino acid replacements L167W/P172L in wild-type ThaBgl (ThaBgl-WT) dramatically increased the properties of glucose-tolerant ThaBgl (ThaBgl-Mut) [18]. The catalytic efficiency parameter $\left(k_{\text {cat }} / K_{m}\right)$ of ThaBgl-Mut $\left(7.85 \pm 0.22 \mathrm{~s}^{-1} / 0.41 \pm 0.30 \mathrm{mM}\right)$ was approximately 5 -fold higher than that of ThaBgl-WT $\left(4.92 \pm 0.54 \mathrm{~s}^{-1} / 1.17 \pm 0.66 \mathrm{mM}\right)$. In the crystal structure, ThaBgl-WT showed a wider aglycone channel measuring $~ 11 \AA$ in width between Trp338 and Pro172 (Figure 5a), whereas ThaBgl-Mut showed a narrower aglycone channel measuring $\sim 9 \AA$ A between Trp338 and Leu172 [18] (Figure 5b). This active-site topology is similar to high glucose-tolerant HinBgl [31], which exhibited an aglycone channel width of $\sim 9 \AA$ between Trp349 and Leu173 (Figure 5c). These results suggested the superb tolerance to high glucose concentrations owing to the reduced distance between the two sides of the active site entrance channel [18]. Additionally, TsaBgl also harbors a narrow aglycone channel of $\sim 9$ A between Trp323 and Le170 (Figure 5d), similar to ThaBgl-Mut and HinBgl; however, the configuration of Trp and Leu residues are different (Figure 5e). To better understand the structural basis for glucose tolerance of TsaBgl, further studies are needed to obtain the Tris-free or other molecule binding state of TsaBgl. 

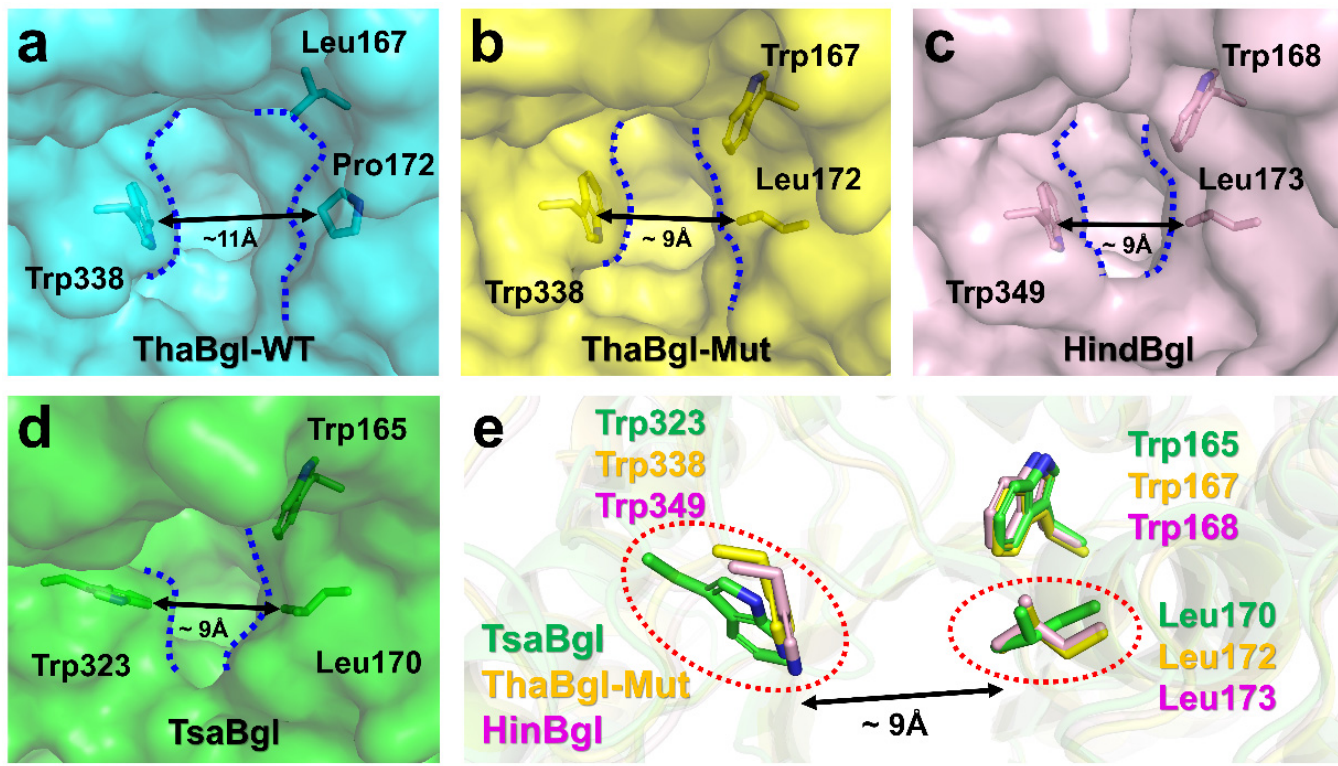

Figure 5. Comparison of the active site pocket of (a) wild-type ThaBgl (PDB code: 5BWF) and (b) engineered ThaBgl (6EFU), (c) HinBgl (4MDO), and (d) TsaBgl. (e) Superimposition of conserved Trp and Leu residues involved in the glucose tolerance of TsaBgl, ThaBgl-Mut, and HinBgl.

In conclusion, our biochemical and structural analysis of TsaBgl is expected to improve our understanding of the $\mathrm{Bgl}$ family and provides new insights into the utilization of $\mathrm{Bgl}$ for industrial applications.

\section{Materials and Methods}

\subsection{Protein Preparation}

A construct containing codon-optimized full-length TsaBgl (accession number: MW655874) with an N-terminally fused hexahistidine-tag was synthesized and cloned into the pBT7 vector (Bioneer, Korea). Recombinant DNA was transformed into Escherichia coli BL21 (DE3). Cells were grown at $37^{\circ} \mathrm{C}$ in $\mathrm{LB}$ medium with $50 \mathrm{mg} / \mathrm{mL}$ ampicillin until reaching an $\mathrm{OD}_{600}$ of 0.4. Protein expression was induced with $0.5 \mathrm{mM}$ isopropyl-D-1-thiogalactopyranoside, and the cells were cultured at $18{ }^{\circ} \mathrm{C}$ for $18 \mathrm{~h}$. After cell harvesting by centrifugation, the cells were resuspended in lysis buffer containing $50 \mathrm{mM}$ Tris- $\mathrm{HCl}(\mathrm{pH} 8.0), 200 \mathrm{mM} \mathrm{NaCl}$, and $20 \mathrm{mM}$ imidazole. The cells were lysed by sonication on ice, and cell debris was removed by centrifugation at $18,894 \times g$ for $30 \mathrm{~min}$. The supernatant was loaded onto a Ni-NTA column (Qiagen, Valencia, CA, USA). The column was washed and equilibrated with lysis buffer, and the protein was subsequently eluted with a buffer containing $50 \mathrm{mM}$ Tris- $\mathrm{HCl}(\mathrm{pH} 8.0)$, $200 \mathrm{mM} \mathrm{NaCl}$, and $300 \mathrm{mM}$ imidazole. To remove the $\mathrm{N}$-terminal hexahistidine-tag, 10 units of thrombin (Sigma Aldrich, St. Louis, MO, USA) were added per milligram of TsaBgl fraction and incubated overnight at $20^{\circ} \mathrm{C}$. The protein was concentrated using a Centricon filter (Merck Millipore, Burlington, MA, USA; cut-off: $30 \mathrm{kDa}$ ), applied onto a Sephacryl-100 column (GE Healthcare, Chicago, IL, USA), and eluted with a buffer containing $10 \mathrm{mM}$ Tris- $\mathrm{HCl}$ (pH 8.0) and $200 \mathrm{mM} \mathrm{NaCl}$. Protein concentration was determined based on the Bradford assay by measuring the absorbance at $595 \mathrm{~nm}$, and subsequently checking against the calibration curve constructed using bovine serum albumin (BSA) as the standard.

\subsection{Biochemical Analysis of TsBgl}

Enzyme activity of TsaBgl was investigated by measuring the formation of $p$-nitrophenol $(p N P)$ from the enzymatic hydrolysis of $p$-nitrophenyl- $\beta$-D-glucopyranoside ( $p N P G), p$ nitrophenyl- $\beta$-D-cellobioside ( $p$ NPC), and $p$-nitrophenyl- $\alpha$-D-glucopyranoside ( $p N P \alpha G)$ (Sigma-Aldrich, St. Louis, MO, USA). In general, enzyme reactions were performed with $7.5 \mu \mathrm{g} / \mathrm{mL}$ TsaBgl in $100 \mathrm{mM}$ sodium phosphate (pH 6.0) containing $2.5 \mathrm{mM} p \mathrm{NPG}$ at 
$55^{\circ} \mathrm{C}$ for $5 \mathrm{~min}$ in a total volume of $100 \mu \mathrm{L}$. Enzyme reactions were terminated by adding $66 \mu \mathrm{L}$ of $1 \mathrm{M} \mathrm{Na}_{2} \mathrm{CO}_{3}$. The amount of $p \mathrm{NP}$ produced was measured at $405 \mathrm{~nm}$ using a Synergy $\mathrm{H} 1$ microplate reader (BioTek Instruments Inc., Winooski, VT, USA) at $25{ }^{\circ} \mathrm{C}$ and calculated from a calibration curve using $p \mathrm{NP}$ as the standard. One unit (U) of enzyme activity was defined as the amount of enzyme required to release $1 \mu \mathrm{mol}$ of $p \mathrm{NP}$ per min from $2.5 \mathrm{mM} p \mathrm{NPG}$.

To examine the effects of $\mathrm{pH}$ on the activity of TsaBgl, enzyme activity was measured in the $\mathrm{pH}$ range $4.0-10.0$ at $55{ }^{\circ} \mathrm{C}$ using a four buffer systems: $100 \mathrm{mM}$ sodium citrate (pH 4.0-6.0), $100 \mathrm{mM}$ sodium phosphate (pH 6.0-7.0), $100 \mathrm{mM}$ Tris- $\mathrm{HCl}$ (pH 7.0-9.0), and $100 \mathrm{mM}$ glycine- $\mathrm{NaOH}$ (pH 9.0-10.0).

To investigate the effects of temperature on the activity of TsaBgl, the enzyme reaction was examined using $2.5 \mathrm{mM}$ pNPG in $100 \mathrm{mM}$ sodium phosphate buffer ( $\mathrm{pH} 7.0$ ) for $5 \mathrm{~min}$ at different temperatures ranging from 30 to $70{ }^{\circ} \mathrm{C}$. For thermal stability analysis, residual enzyme activity was measured after pre-incubating TsaBgl at specified temperatures in the absence of substrate. In detail, $7.5 \mu \mathrm{g} / \mathrm{mL}$ TsaBgl was pre-incubated at temperatures ranging from 30 to $80^{\circ} \mathrm{C}$ for $10 \mathrm{~min}$ in $100 \mathrm{mM}$ sodium phosphate ( $\mathrm{pH} \mathrm{6.0)}$ ) before running the enzyme reaction for $5 \mathrm{~min}$ by adding $2.5 \mathrm{mM} p$ NPG under standard conditions $\left(55^{\circ} \mathrm{C}\right.$ and $\mathrm{pH}$ 6.0). Relative activity (\%) represents the residual enzyme activity relative to that determined without pre-incubation.

To investigate the effects of metal on the activity of TsaBgl, enzyme activity was measured under optimal conditions $\left(55^{\circ} \mathrm{C}\right.$ and $\mathrm{pH} 6.0$ in $100 \mathrm{mM}$ sodium phosphate) in the presence of $1 \mathrm{mM}$ of various metal ions, such as $\mathrm{LiSO}_{4}, \mathrm{MgCl}_{2}, \mathrm{CaCl}_{2}, \mathrm{MnCl}_{2}, \mathrm{FeCl}_{2}$, $\mathrm{FeCl}_{3}, \mathrm{CoCl}_{2}, \mathrm{NiCl}_{2}, \mathrm{CuCl}_{2}, \mathrm{ZnCl}_{2}, \mathrm{CdCl}_{2}$, and $\mathrm{CeCl}_{2}$.

Kinetic parameters $\left(K_{m}, k_{c a t}\right.$, and $\left.k_{c a t} / K_{m}\right)$ were determined by conducting the enzymatic reaction with $7.5 \mu \mathrm{g} / \mathrm{mL}$ TsaBgl in various concentrations (0 to $10 \mathrm{mM}$ ) of $p$ NPG at the optimal condition ( $\mathrm{pH} 6.0$ and $55^{\circ} \mathrm{C}$ ). Data fitting was performed using the MichaelisMenten equation based on SigmaPlot 12.3 software (Systat Software, Erkrath, Germany).

To investigate the tolerance of TsaBgl to Tris and glucose, we performed the enzymatic reaction under the standard conditions and in the absence or presence of different concentrations of Tris (0-210 mM) or glucose $(0-830 \mathrm{mM})$ from $1 \mathrm{M}(\mathrm{pH} 7.0)$ or $2 \mathrm{M}$ stock, respectively. In case of Tris inhibition, the enzyme assay was performed at pH 7 (100 mM sodium phosphate) to prevent the potential effect of Tris on $\mathrm{pH}$ change in the reaction solution. The relative activity (\%) represents the enzyme activity relative to that determined in the absence of Tris or glucose.

\subsection{Crystallizations}

Purified TsaBgl was concentrated to $30 \mathrm{mg} / \mathrm{mL}$ using a Centricon filter (Merck; cut-off: $30 \mathrm{kDa}$ ). Initial crystallization conditions of TsaBgl were screened using the sitting-drop vapor diffusion method at $22^{\circ} \mathrm{C}$ using a Crystal Screen Kit (Hampton Research, Aliso Viejo, CA, USA). Microcrystals were obtained in reservoir solution containing $0.1 \mathrm{M}$ Tris- $\mathrm{HCl}$ ( $\mathrm{pH} 8.5$ ), 30\% (w/v) PEG 4000, and $0.2 \mathrm{M} \mathrm{MgCl}_{2}$. Crystallization conditions were further optimized by the hanging-drop vapor diffusion method at $22{ }^{\circ} \mathrm{C}$. Rod-shaped TsaBgl crystals were obtained within 1 week by mixing $2 \mu \mathrm{L}$ protein solution with $2 \mu \mathrm{L}$ reservoir solution, followed by equilibration against $500 \mu \mathrm{L}$ of $0.1 \mathrm{M}$ Tris- $\mathrm{HCl}(\mathrm{pH} 7.0), 27 \%(w / v)$ PEG 3350, and $0.2 \mathrm{M} \mathrm{MgCl}_{2}$.

\subsection{X-ray Diffraction Data Collection}

X-ray diffraction data were collected on a Beamline 11C at the Pohang Light Source II (PLS-II; Pohang, Korea) [47]. The crystals were transferred into a cryoprotectant solution containing the reservoir solution supplemented with $25 \%(v / v)$ ethylene glycol and then flash-frozen in a liquid nitrogen stream at $100 \mathrm{~K}$. Diffraction images were indexed, integrated, and scaled using HKL2000 [48]. 


\subsection{Structure Determination and Analysis}

The structure was solved by molecular replacement with MOLPEP [49], using the crystal structure of engineered Bgl from a soil metagenome library (PDB code: 4HZ6) [50] as a search model. The model was manually built using the COOT program [51]. Model refinement was performed using REFMAC5 [52]. The geometry of the final model was evaluated using MolProbity [53]. Structure figures were prepared using PyMOL (DeLano Scientific LLC, San Carlos, CA, USA). Structure-based sequence alignments were created with Clustal-Omega [54] and ESPript [55]. Homologous structures were searched using DALI server [56].

Supplementary Materials: The following are available online, Figure S1: Effect of $1 \mathrm{mM}$ of Tris on the activity of TsaBgl; Figure S2: 2Fo-Fc electron density map of Tris and Tris-binding residues of TsaBgl; Figure S3: Interaction between the N and C Termini of TsaBgl, Figure S4: Superimposition of TsaBgl with other Bgls, Figure S5: Sequence alignment of TsaBgl with other Bgls, Figure S6: Comparison of TsaBgl with other Bgls.

Author Contributions: I.J.K. and K.H.N. designed, conceived research, conducted experiments and wrote the manuscript. U.T.B. provided resources and revised the manuscript. All authors have read and agreed to the published version of the manuscript.

Funding: This research was funded by the National Research Foundation of Korea (NRF2020R1A6A3A03039153 to I.J.K., and NRF-2017R1D1A1B03033087, NRF-2017M3A9F6029736, NRF2020M3H1A1075314 and NRF-2021R1I1A1A01050838 to K.H.N.)

Institutional Review Board Statement: Not applicable.

Informed Consent Statement: Not applicable.

Data Availability Statement: The final coordinates and structure factors were deposited in the Protein Data Bank under accession code 7E5J.

Acknowledgments: We thank the beamline staff at the MX beamlines at PLS-II at Pohang Acceleratory Laboratory for assistance in data collection.

Conflicts of Interest: The authors declare no conflict of interest.

Sample Availability: Samples of the compounds are not available from the authors.

\section{References}

1. Sims, R.E.; Mabee, W.; Saddler, J.N.; Taylor, M. An overview of second generation biofuel technologies. Bioresour. Technol. 2010, 101, 1570-1580. [CrossRef] [PubMed]

2. Lynd, L.; Zyl, W.; McBride, J.; Laser, M. Consolidated bioprocessing of cellulosic biomass: An update. Curr. Opin. Biotechnol. 2005, 16, 577-583. [CrossRef]

3. Lynd, L.R.; Laser, M.S.; Bransby, D.; Dale, B.E.; Davison, B.; Hamilton, R.; Himmel, M.; Keller, M.; McMillan, J.D.; Sheehan, J.; et al. How biotech can transform biofuels. Nat. Biotechnol. 2008, 26, 169-172. [CrossRef]

4. Himmel, M.E.; Ding, S.Y.; Johnson, D.K.; Adney, W.S.; Nimlos, M.R.; Brady, J.W.; Foust, T.D. Biomass recalcitrance: Engineering plants and enzymes for biofuels production. Science 2007, 315, 804-807. [CrossRef]

5. Jalak, J.; Kurašin, M.; Teugjas, H.; Väljamäe, P. Endo-exo synergism in cellulose hydrolysis revisited. J. Biol. Chem. 2012, 287, 28802-28815. [CrossRef]

6. Kim, I.J.; Jung, J.Y.; Lee, H.J.; Park, H.S.; Jung, Y.H.; Park, K.; Kim, K.H. Customized optimization of cellulase mixtures for differently pretreated rice straw. Bioprocess Biosyst. Eng. 2014, 38, 929-937. [CrossRef]

7. Kim, I.J.; Lee, H.J.; Kim, K.H. Pure enzyme cocktails tailored for the saccharification of sugarcane bagasse pretreated by using different methods. Process Biochem. 2017, 57, 167-174. [CrossRef]

8. Gilbert, H.; Stalbrand, H.; Brumer, H. How the walls come crumbling down: Recent structural biochemistry of plant polysaccharide degradation. Curr. Opin. Plant Biol. 2008, 11, 338-348. [CrossRef]

9. Kern, M.; McGeehan, J.E.; Streeter, S.D.; Martin, R.N.A.; Besser, K.; Elias, L.; Eborall, W.; Malyon, G.P.; Payne, C.M.; Himmel, M.E.; et al. Structural characterization of a unique marine animal family 7 cellobiohydrolase suggests a mechanism of cellulase salt tolerance. Proc. Natl. Acad. Sci. USA 2013, 110, 10189-10194. [CrossRef]

10. Lombard, V.; Golaconda Ramulu, H.; Drula, E.; Coutinho, P.M.; Henrissat, B. The carbohydrate-active enzymes database (CAZy) in 2013. Nucleic Acids Res. 2014, 42, D490-D495. [CrossRef] 
11. Isorna, P.; Polaina, J.; Latorre-García, L.; Cañada, F.J.; González, B.; Sanz-Aparicio, J. Crystal structures of Paenibacillus polymyxa $\beta$-glucosidase $B$ complexes reveal the molecular basis of substrate specificity and give new insights into the catalytic machinery of family I glycosidases. J. Mol. Biol. 2007, 371, 1204-1218. [CrossRef]

12. Lopez-Camacho, C.; Salgado, J.; Lequerica, J.L.; Madarro, A.; Ballestar, E.; Franco, L.; Polaina, J. Amino acid substitutions enhancing thermostability of Bacillus polymyxa $\beta$-glucosidase A. Biochem. J. 1996, 314, 833-838. [CrossRef]

13. González-Blasco, G.; Sanz-Aparicio, J.; González, B.; Hermoso, J.A.; Polaina, J. Directed evolution of $\beta$-glucosidase A from Paenibacillus polymyxa to thermal resistance. J. Biol. Chem. 2000, 275, 13708-13712. [CrossRef]

14. Arrizubieta, M.a.J.; Polaina, J. Increased thermal resistance and modification of the catalytic properties of a $\beta$-glucosidase by random mutagenesis and in vitro recombination. J. Biol. Chem. 2000, 275, 28843-28848. [CrossRef]

15. Zubillaga, R.; Garcia-Hernandez, E.; Camarillo-Cadena, M.; Leon, M.; Polaina, J. Effect of a new ionic pair on the unfolding activation barrier of $\alpha$-glucosidase B. Protein Pept. Lett. 2006, 13, 113-118. [CrossRef]

16. Borges, D.G.; Baraldo Junior, A.; Farinas, C.S.; de Lima Camargo Giordano, R.; Tardioli, P.W. Enhanced saccharification of sugarcane bagasse using soluble cellulase supplemented with immobilized $\beta$-glucosidase. Bioresour. Technol. 2014, 167, 206-213. [CrossRef]

17. Krogh, K.B.R.M.; Harris, P.V.; Olsen, C.L.; Johansen, K.S.; Hojer-Pedersen, J.; Borjesson, J.; Olsson, L. Characterization and kinetic analysis of a thermostable GH3 $\beta$-glucosidase from Penicillium brasilianum. Appl. Microbiol. Biotechnol. 2009, 86, 143-154. [CrossRef]

18. Santos, C.A.; Morais, M.A.B.; Terrett, O.M.; Lyczakowski, J.J.; Zanphorlin, L.M.; Ferreira-Filho, J.A.; Tonoli, C.C.C.; Murakami, M.T.; Dupree, P.; Souza, A.P. An engineered GH1 $\beta$-glucosidase displays enhanced glucose tolerance and increased sugar release from lignocellulosic materials. Sci. Rep. 2019, 9, 4903. [CrossRef]

19. Chang, T.; Yao, S. Thermophilic, lignocellulolytic bacteria for ethanol production: Current state and perspectives. Appl. Microbiol. Biotechnol. 2011, 92, 13-27. [CrossRef]

20. Currie, D.H.; Raman, B.; Gowen, C.M.; Tschaplinski, T.J.; Land, M.L.; Brown, S.D.; Covalla, S.F.; Klingeman, D.M.; Yang, Z.K.; Engle, N.L.; et al. Genome-scale resources for Thermoanaerobacterium saccharolyticum. BMC Syst. Biol. 2015, 9, 30. [CrossRef]

21. Shaw, A.J.; Podkaminer, K.K.; Desai, S.G.; Bardsley, J.S.; Rogers, S.R.; Thorne, P.G.; Hogsett, D.A.; Lynd, L.R. Metabolic engineering of a thermophilic bacterium to produce ethanol at high yield. Proc. Natl. Acad. Sci. USA 2008, 105, 13769-13774. [CrossRef]

22. Lee, Y.E.; Jain, M.K.; Lee, C.; Zeikus, J.G. Taxonomic distinction of saccharolytic thermophilic anaerobes: Description of Thermoanaerobacterium xylanolyticum gen. nov., sp. nov., and Thermoanaerobacterium saccharolyticum gen. nov., sp. nov.; Reclassification of Thermoanaerobium brockii, Clostridium thermosulfurogenes, and Clostridium thermohydrosulfuricum E100-69 as Thermoanaerobacter brockii comb. nov., Thermoanaerobacterium thermosulfurigenes comb. nov., and Thermoanaerobacter thermohydrosulfuricus comb. nov., Respectively; and Transfer of Clostridium thermohydrosulfuricum 39E to Thermoanaerobacter ethanolicus. Int. J. Syst. Bacteriol. 1993, 43, 41-51. [CrossRef]

23. Podkaminer, K.K.; Guss, A.M.; Trajano, H.L.; Hogsett, D.A.; Lynd, L.R. Characterization of xylan utilization and discovery of a new endoxylanase in Thermoanaerobacterium saccharolyticum through targeted gene deletions. Appl. Environ. Microbiol. 2012, 78, 8441-8447. [CrossRef]

24. Vocadlo, D.J.; Wicki, J.; Rupitz, K.; Withers, S.G. Mechanism of Thermoanaerobacterium saccharolyticum $\beta$-Xylosidase: Kinetic Studies. Biochemistry 2002, 41, 9727-9735. [CrossRef] [PubMed]

25. Bronnenmeier, K.; Meissner, H.; Stocker, S.; Staudenbauer, W.L. $\alpha$-D-Glucuronidases from the xylanolytic thermophiles Clostridium stercorarium and Thermoanaerobacterium saccharolyticum. Microbiology 1995, 141, 2033-2040. [CrossRef] [PubMed]

26. Ramesh, M.V.; Podkovyrov, S.M.; Lowe, S.E.; Zeikus, J.G. Cloning and sequencing of the Thermoanaerobacterium saccharolyticum B6A-RI apu gene and purification and characterization of the amylopullulanase from Escherichia coli. Appl. Environ. Microbiol. 1994, 60, 94-101. [CrossRef] [PubMed]

27. Nam, K.H.; Kim, S.J.; Kim, M.Y.; Kim, J.H.; Yeo, Y.S.; Lee, C.M.; Jun, H.K.; Hwang, K.Y. Crystal structure of engineered $\beta$-glucosidase from a soil metagenome. Proteins 2008, 73, 788-793. [CrossRef]

28. Ketudat Cairns, J.R.; Esen, A. $\beta$-Glucosidases. Cell. Mol. Life Sci. 2010, 67, 3389-3405. [CrossRef] [PubMed]

29. Jeng, W.-Y.; Wang, N.-C.; Lin, M.-H.; Lin, C.-T.; Liaw, Y.-C.; Chang, W.-J.; Liu, C.-I.; Liang, P.-H.; Wang, A.H.J. Structural and functional analysis of three $\beta$-glucosidases from bacterium Clostridium cellulovorans, fungus Trichoderma reesei and termite Neotermes koshunensis. J. Struct. Biol. 2011, 173, 46-56. [CrossRef] [PubMed]

30. Miao, L.-L.; Hou, Y.-J.; Fan, H.-X.; Qu, J.; Qi, C.; Liu, Y.; Li, D.-F.; Liu, Z.-P.; Schottel, J.L. Molecular structural basis for the cold adaptedness of the psychrophilic $\beta$-glucosidase BglU in Micrococcus antarcticus. Appl. Environ. Microbiol. 2016, 82, 2021-2030. [CrossRef]

31. De Giuseppe, P.O.; Souza Tde, A.; Souza, F.H.; Zanphorlin, L.M.; Machado, C.B.; Ward, R.J.; Jorge, J.A.; Furriel Rdos, P.; Murakami, M.T. Structural basis for glucose tolerance in GH1 $\beta$-glucosidases. Acta Crystallogr. D Biol. Crystallogr. 2014, 70, 1631-1639. [CrossRef] [PubMed]

32. Tankrathok, A.; Iglesias-Fernández, J.; Williams, R.J.; Pengthaisong, S.; Baiya, S.; Hakki, Z.; Robinson, R.C.; Hrmova, M.; Rovira, C.; Williams, S.J.; et al. A single glycosidase harnesses different pyranoside ring transition state conformations for hydrolysis of mannosides and glucosides. ACS Catalysis 2015, 5, 6041-6051. [CrossRef]

33. Permyakov, E.A.; Tamaki, F.K.; Souza, D.P.; Souza, V.P.; Ikegami, C.M.; Farah, C.S.; Marana, S.R. Using the amino acid network to modulate the hydrolytic activity of $\beta$-glycosidases. PLOS ONE 2016, 11, e0167978. [CrossRef] 
34. Liu, X.; Cao, L.; Zeng, J.; Liu, Y.; Xie, W. Improving the cellobiose-hydrolysis activity and glucose-tolerance of a thermostable $\beta$-glucosidase through rational design. Int. J. Biol. Macromol. 2019, 136, 1052-1059. [CrossRef] [PubMed]

35. Salgado, J.C.S.; Meleiro, L.P.; Carli, S.; Ward, R.J. Glucose tolerant and glucose stimulated $\beta$-glucosidases-A review. Bioresour. Technol. 2018, 267, 704-713. [CrossRef] [PubMed]

36. Pei, J.; Pang, Q.; Zhao, L.; Fan, S.; Shi, H. Thermoanaerobacterium thermosaccharolyticum $\beta$-glucosidase: A glucose-tolerant enzyme with high specific activity for cellobiose. Biotechnol. Biofuels 2012, 5, 31. [CrossRef] [PubMed]

37. Crespim, E.; Zanphorlin, L.M.; de Souza, F.H.M.; Diogo, J.A.; Gazolla, A.C.; Machado, C.B.; Figueiredo, F.; Sousa, A.S.; Nóbrega, F.; Pellizari, V.H.; et al. A novel cold-adapted and glucose-tolerant GH1 $\beta$-glucosidase from Exiguobacterium antarcticum B7. Int. J. Biol. Macromol. 2016, 82, 375-380. [CrossRef] [PubMed]

38. Xue, Y.; Xue, M.; Xie, F.; Zhang, M.; Zhao, H.; Zhou, T. Engineering Thermotoga maritima $\beta$-glucosidase for improved alkyl glycosides synthesis by site-directed mutagenesis. J. Ind. Microbiol. Biotechnol. 2021, 48, kuab031. [CrossRef] [PubMed]

39. Czjzek, M.; Cicek, M.; Zamboni, V.; Bevan, D.R.; Henrissat, B.; Esen, A. The mechanism of substrate (aglycone) specificity in $\beta$-glucosidases is revealed by crystal structures of mutant maize $\beta$-glucosidase-DIMBOA, -DIMBOAGlc, and -dhurrin complexes. Proc. Natl. Acad. Sci. USA 2000, 97, 13555-13560. [CrossRef] [PubMed]

40. Ait, N.; Creuzet, N.; Cattaneo, J. Properties of $\beta$-glucosidase purified from Clostridium thermocellum. Microbiology 1982, 128, 569-577. [CrossRef]

41. Ferreira, C.; Terra, W.R. Physical and kinetic properties of a plasma-membrane-bound $\beta$-D-glucosidase (cellobiase) from midgut cells of an insect (Rhynchosciara americana larva). Biochem. J. 1983, 213, 43-51. [CrossRef]

42. Park, S.-Y.; Bae, E.-A.; Sung, J.H.; Lee, S.-K.; Kim, D.-H. Purification and characterization of ginsenoside Rb1-metabolizing $\beta$-glucosidase from Fusobacterium K-60, a human intestinal anaerobic bacterium. Biosci. Biotechnol. Biochem. 2014, 65, 1163-1169. [CrossRef] [PubMed]

43. Cao, L.-C.; Wang, Z.-J.; Ren, G.-H.; Kong, W.; Li, L.; Xie, W.; Liu, Y.-H. Engineering a novel glucose-tolerant $\beta$-glucosidase as supplementation to enhance the hydrolysis of sugarcane bagasse at high glucose concentration. Biotechnol. Biofuels 2015, 8, 202. [CrossRef] [PubMed]

44. Lee, H.L.; Chang, C.K.; Jeng, W.Y.; Wang, A.H.J.; Liang, P.H. Mutations in the substrate entrance region of $\beta$-glucosidase from Trichoderma reesei improve enzyme activity and thermostability. Protein Eng. Des. Sel. 2012, 25, 733-740. [CrossRef] [PubMed]

45. Liu, J.; Zhang, X.; Fang, Z.; Fang, W.; Peng, H.; Xiao, Y. The 184th residue of $\beta$-glucosidase Bgl1B plays an important role in glucose tolerance. J. Biosci. Bioeng. 2011, 112, 447-450. [CrossRef] [PubMed]

46. Sinha, S.K.; Prakash Reddy, K.; Datta, S. Understanding the glucose tolerance of an archaeon $\beta$-glucosidase from Thermococcus sp. Carbohyd. Res. 2019, 486, 107835. [CrossRef] [PubMed]

47. Park, S.Y.; Ha, S.C.; Kim, Y.G. The protein crystallography beamlines at the Pohang Light Source II. Biodesign 2017, 5, 30-34.

48. Otwinowski, Z.; Minor, W. Processing of X-ray diffraction data collected in oscillation mode. Methods Enzymol. 1997, 276, 307-326. [PubMed]

49. Vagin, A.; Teplyakov, A. Molecular replacement with MOLREP. Acta Crystallogr. D Biol. Crystallogr. 2010, 66, 22-25. [CrossRef] [PubMed]

50. Nam, K.H.; Sung, M.W.; Hwang, K.Y. Structural insights into the substrate recognition properties of $\beta$-glucosidase. Biochem. Biophys. Res. Commun. 2010, 391, 1131-1135. [CrossRef] [PubMed]

51. Emsley, P.; Cowtan, K. Coot: Model-building tools for molecular graphics. Acta Crystallogr. D Biol. Crystallogr. 2004, 60, 2126-2132. [CrossRef]

52. Murshudov, G.N.; Skubák, P.; Lebedev, A.A.; Pannu, N.S.; Steiner, R.A.; Nicholls, R.A.; Winn, M.D.; Long, F.; Vagin, A.A REFMAC5 for the refinement of macromolecular crystal structures. Acta Crystallogr. D Biol. Crystallogr. 2011, 67, 355-367. [CrossRef] [PubMed]

53. Williams, C.J.; Headd, J.J.; Moriarty, N.W.; Prisant, M.G.; Videau, L.L.; Deis, L.N.; Verma, V.; Keedy, D.A.; Hintze, B.J.; Chen, V.B.; et al. MolProbity: More and better reference data for improved all-atom structure validation. Protein Sci. 2018, 27, 293-315. [CrossRef] [PubMed]

54. Sievers, F.; Wilm, A.; Dineen, D.; Gibson, T.J.; Karplus, K.; Li, W.; Lopez, R.; McWilliam, H.; Remmert, M.; Soding, J.; et al. Fast, scalable generation of high-quality protein multiple sequence alignments using Clustal Omega. Mol. Syst. Biol. 2011, 7, 539. [CrossRef]

55. Gouet, P.; Courcelle, E.; Stuart, D.I.; Metoz, F. ESPript: Analysis of multiple sequence alignments in PostScript. Bioinformatics 1999, 15, 305-308. [CrossRef]

56. Holm, L.; Rosenstrom, P. Dali server: Conservation mapping in 3D. Nucleic Acids Res. 2010, 38, W545-W549. [CrossRef] [PubMed] 